\title{
Seed Germination, Post-fire Plant Growth and Conservation of the Rare Endemic and Endangered Chamaecrista glandulosa var. mirabilis (Fabaceae)
}

Fernando J. Vilá Terrada ${ }^{1,2, *}$ and Jonathan A. López Colón ${ }^{1,2, *}$

${ }^{1}$ School of Sciences, Technology, and Environment, Ana G. Méndez University, Cupey Campus, San Juan, Puerto Rico 00928. ²Department of Biology, University of Puerto Rico, Río Piedras Campus, San Juan, Puerto Rico 00931. *Corresponding authors - fernandojvt578@gmail.com, 787-220-6977; jonathan.lopez30@upr.edu, 939-588-9493.

\begin{abstract}
Conservation has been challenged by biodiversity loss drivers. Also, fire disturbance can temporarily change ecosystems. Fire effects in soil nutrients and $\mathrm{pH}$, plant abundance, reproduction, seed weight, seed germination, and plant growth were assessed. Four seed starting systems were used for germination and growth under laboratory conditions. We found significant differences in the means of iron, manganese, nickel, soil $\mathrm{pH}$, and plant height, and a significant positive linear relationship between seed weight and plant height. Results indicate that fires increase soil $\mathrm{pH}$ and cause changes in micronutrients that can increase plant growth. Large size plants are produced from high weight seeds. Finally, ex situ conservation and species reintroduction were feasible conservation strategies that should be integrated with in situ conservation.
\end{abstract}

Keywords: Seed germination, Seed characterization, Plant growth, Fire, Soil chemistry, Conservation.

\section{Introduction}

Ecosystems are sensitive to natural and anthropogenic disturbances (Adeney et al. 2016) that change biodiversity. Endangered rare endemic species are of priority for conservation due to its restricted and narrow geographic distribution, small abundance, and critical state.

Conservation has been challenged by the increasing biodiversity loss drivers like habitat loss and change, overexploitation, pollution, invasive species, and climate change (Heywood 2017). Conservation biology addresses the biology of species, communities, and ecosystems that are 
perturbed with the goal of providing principles for preserving and protecting biodiversity (Soulé 1985). Plant conservation is dependent on the creation of protected areas and parks and is complemented by conservation strategies and research in population biology (Soulé 1985, Heywood 2017), including environmental conditions experiments.

Fire disturbance has the ability to temporarily produce significant changes to organic matter, chemical properties, and ecosystems (Bridges et al. 2019). Natural charcoal and ash from wildfire have the potential to alter the soil solution chemistry (Gundale and DeLuca 2006). Plant available nitrogen and total phosphorus concentrations were found to increase in burned soils (Kutiel and Naveh 1987, Paritsis et al. 2006), but decreases in exchangeable potassium (Bridges et al. 2019), dissolved nitrogen and soil moisture (Knelman et al. 2017) have also been found. Specifically, increases in available calcium, magnesium, and phosphorus have resulted from high intensity fires (Bridges et al. 2019), and decreases in carbon and nitrogen concentrations were caused by high fire frequencies (Pellegrini et al. 2018). Advances in flowering and fruiting onset and greater fruit set (Paritsis et al. 2006), along increases in shoot and root biomass, seed number, and seed weight (Kutiel and Naveh 1987) have resulted in burned environments.

Growth, irreversible increase in size, form, or number with time (Hunt 2003), can have implications for the life cycle of plants. The growth and distribution of plants are controlled by the interaction of gene mechanisms and the environment, which includes factors like radiation, temperature, water, atmospheric gases, soil chemistry, and biotic factors, among others (Billings 1952). Plant size was found to be positively correlated with absolute growth (McIntosh 2002), positively correlated with the number of buds, flowers, and fruits produced by plant (RojasSandoval and Meléndez-Ackerman 2011), and positively related to inflorescence size (Rodríguez-Robles et al. 1992). Also, greater plant size (Dollard 2018) and absolute plant and root mass (Schreeg et al. 2005) may be related with high survival. Therefore, greater plant growth and size promotes reproduction and survival that can influence population size and the preservation of species.

Seeds are an important source for plant propagation. Seed weight was found to be positively correlated with plant size (Hendrix 1984), and similarly, seed mass was positively correlated with shoot mass, root mass, and shoot length (Mukherjee et al. 2019). Large seed weight showed higher germination percentage (Anjusha et al. 2015), and high seed weight and width resulted in faster germination (Xu et al. 2016). Seed germination is the process of seedling 
formation that initiates with the uptake of water (imbibition), the reactivation of cellular and metabolic processes, and the extension of the radicle or embryonic root (Bewley 1997). Abiotic factors that influence seed germination include soil pH (Singh et al. 1975), light, temperature, soil type, and sowing depth (Shen et al. 2015).

Main conservation strategies for plants are in situ and ex situ conservation and species reintroduction (Ren et al. 2014). Propagation from seeds was found a viable method for ex situ conservation (Cerabolini et al. 2004). Species reintroduction is the bridge between in situ and ex situ conservation and is the final goal of ex situ conservation (Ren et al. 2014). Augmentation, a main concept of reintroduction, refers to population reinforcement when individuals are added to an existing population increasing the population size or genetic diversity (Ren et al. 2014). The use of seedlings and mixing material from diverse populations promoted higher survival rates in reintroductions (Godefroid et al. 2011). Finally, transplants as founders yielded greater establishment rates than seeds (Guerrant Jr and Kaye 2007).

Studies on ex situ plant development and field establishment following transplantation are required for species reintroductions (Cerabolini et al. 2004). Field observations suggested differences in population size and plant growth between populations of the study species. The main objectives were to propagate from seeds, germinate in field and laboratory conditions, and test ex situ conservation and reintroduction as reinforcement. Fire effects in soil nutrients and $\mathrm{pH}$, plant abundance, and reproduction in the field were examined. Also, fire effects in seed weight, seed germination, and plant growth in the laboratory were assessed. The first question was, what are the effects of fire on soil nutrients and $\mathrm{pH}$ ? Second, what are the effects of postfire soil nutrients and $\mathrm{pH}$ on the species? We hypothesized that soil nutrients and $\mathrm{pH}$ will increase after fire and positively affect seed weight, plant growth, reproduction, and plant abundance in the fire affected population. At last, is seed germination related to soil $\mathrm{pH}$, and is plant height related to seed weight? We hypothesized that seed germination will be related to soil $\mathrm{pH}$ and plant height will be positively related to seed weight.

\section{Materials and Methods}

\section{Study species}


Chamaecrista glandulosa var. mirabilis (Pollard 1902) (Fig. 1a) is a rare endemic and endangered plant species in Puerto Rico. It belongs to the Fabaceae family and Caesalpinioideae subfamily. It is endemic to white silica sands of the north coast of Puerto Rico at elevations near sea level (USFWS 1994). The species was classified as endangered on April 5, 1990 according to the Endangered Species Act of 1973 (USFWS 2015). It is endangered due to sand extraction, deforestation, and urban and industrial expansion (USFWS 1994). Main threats include habitat destruction, habitat modification, climate change, invasive plant species, and human-induced fires (USFWS 2015).

The species is a small perennial shrub. The plant grows from 1-8 cm tall prostrated or assurgent. Leaves are compound paripinnate with alternate arrangement, measuring up to $4.5 \mathrm{~cm}$ long. Leaflets are linear-elliptic with 10-18 pairs, and measure up to $7.5 \mathrm{~mm}$ long and $1.4 \mathrm{~mm}$ broad. Solitary flowers have 3 short petals and a big long abaxial petal. The corolla is yellow. The fruit is a flat dehiscent legume, 18-40 mm long, 3-3.8 mm broad, and seeds are 2.2-2.9 mm long (Liogier 1988).

\section{Study site}

Two populations were studied in a tropical coastal wetland at Reserva Natural Laguna Tortuguero (RNLT), located between the municipalities of Vega Baja and Manatí (18²7'48' 'N, 662'ㅇ' 'W) on the north coast of Puerto Rico. The wetland includes a marsh, swamp, two lagoons, and a dry evergreen or littoral forest (USFWS 1994) within the subtropical moist forest life zone (Miller and Lugo 2009). The soil is white silica $\left(\mathrm{SiO}_{2}\right)$ sand with high acidity, extreme nutrient scarcity, and low organic matter content (Adeney et al. 2016). Puerto Rico has a warm and humid tropical climate. The mean annual air temperature ranges from $24^{\circ} \mathrm{C}$ to $27^{\circ} \mathrm{C}$ in coastal areas, and rainfall is about 1,825 mm in an average year (Gómez-Gómez et al. 2014).

Populations are located on open areas in the forest near the Tortuguero lagoon. Population 1 is located southeast of the lagoon in an open area. Population 2 is located south of the lagoon in a semi-open area with canopy and trails. A human-induced fire occurred in the area of Population 1 in May 2015, affecting the population and serving as an experiment. Experimental observations and tests were conducted in the laboratory and the field.

\section{Sampling and experimental design}


Two hectares (Plot 1 and Plot 2) measuring $100 \mathrm{~m} \mathrm{x} 100 \mathrm{~m}\left(10,000 \mathrm{~m}^{2}\right)$ were established to sample the populations. The experimental design included two groups, the experimental and control. The experimental group was Population 1, which was affected by the fire. The control group was Population 2, which was not affected by fire. Nine replicates of 36 seeds by population were done for the seed germination rate and plant growth. Three were done for germination percent in sand and one for germination percent in different soils. Two replicates were used to sample seed weight and reproduction. And three replicates were used for field germination and transplantation.

\section{Soil samples}

Soil samples were taken in both plots for soil chemistry analysis. Samples were collected in 3 different points as replicates within each plot and divided in 3 for a total of 18 samples (9 in Plot 1; 9 in Plot 2). All samples were collected using a 15 in long stainless-steel tubular sampler, which included the $\mathrm{O}$ (organic) and A (surface) horizons. After collection, the sand soil was divided by organic matter and surface layers and stored in plastic bags. The soil samples were taken to Environmental Quality Laboratories, Inc. for chemical tests after 2 years of the fire event.

\section{Fruit collection}

Mature fruits were collected from adult plants in the field to assess reproduction differences between populations. A total of 107 fruits were collected in each population. They were stored in plastic bags and taken to the laboratory. There, fruits were opened, and seeds were counted per fruit by population. Seeds were stored in centrifuge tubes at ambient temperature. Seeds $(n=216)$ were identified with a number and weighed on a scale by population in the laboratory. Finally, seeds were tracked after sowing to determine seed germination and plant growth. At last, plant abundance was counted according to the development stage of plants (seedling, juvenile, adult) within both plots.

\section{Seed germination}

Four Burpee - 36 Cell Seed Starting Systems were used for seed germination and plant growth under laboratory conditions as part of the experiment. Each system included: a 36-cell 
planting tray, self-watering mat, plant stand, watering tray, and a clear greenhouse dome. Of the four seed starting systems, two were used for the sample of Population 1 and the other two for the sample of Population 2. Silica sand of Plot 1 was added to the cells of planting trays of Population 1, and silica sand of Plot 2 was added to the cells of planting trays of Population 2. Seeds of Population 1 were sowed in the soil on the planting trays of Population 1, and seeds of Population 2 were sowed in the soil on the planting trays of Population 2. Then, a small amount of water was added in each cell with a dropper for imbibition. Finally, the clear greenhouse domes were placed on top of the planting trays for the first two weeks, and water was added to the watering trays.

The four seed starting systems were placed on bigger trays in a rack under a lamp containing two light bulbs (130v 150w 1,150LM). Yellow light from the light bulbs was provided during the day. Light bulbs were powered on every morning and powered off in the afternoon for the night. The photoperiod was established with 10 hours of light and 14 hours of darkness. Water was added to the watering trays every time they were empty to provide humidity. Seeds were monitored almost daily in each system since sowing day for 60 days. They were identified and marked in the cells with little flags made with toothpicks and colored tapes when germination occurred each day. Finally, germinated seeds were counted per day by population to perform the seed germination rate and percent.

Other two germination tests were conducted, seed germination in different soils and in the field. Seeds from both populations were sowed in pots with Pro-Mix potting and seeding mix with Peat moss, potting mix and sand in the surface, garden soil, and Burpee pellets to examine germination on different soils in the laboratory. Later, germinated seeds were counted. For seed germination in the field, three quadrants measuring $1 \mathrm{~m} \mathrm{x} 1 \mathrm{~m}$ were made near Plot 1 . Each quadrant was weeded first and then marked in the corners with flags. Sixteen seeds were sowed in the surface of the soil in each quadrant in the month of November. A total of 48 seeds were used, including seeds of both populations. Also, a plot measuring $3 \mathrm{~m}$ long x $2 \mathrm{~m}$ wide was established using flags near Plot 2. Forty-eight seeds of the species were sowed in the surface of the soil without vegetation in the month of March. At last, another plot measuring $5 \mathrm{~m}$ long x 2 $\mathrm{m}$ wide was made in a new open area to create a population from seeds. Seeds were sowed in soil without vegetation in the month of March. Water was added in the soil surface once in each plot for germination. Finally, seed germination was monitored for 5 months. 


\section{Plant growth}

An analysis using size was made to understand plant growth in the seed starting systems under laboratory conditions. The analysis was made by the classical quantitative method, which involves measurements through time (relatively infrequent long intervals) in a large number of plants (Hunt 2003). After 2 weeks since sowing day (day 15), seedling height was measured in $\mathrm{cm}$ by population with a metric ruler in each seed starting system. Every 2 weeks, juvenile plants were measured again. This was done for a total of 4 measurements until day 57 . After the first measurement, each seedling was identified with a seedling tag and a number.

\section{Acclimation and reintroductions}

Juvenile plants from the seed starting systems were transplanted to pots. Pots were placed in a nursery for acclimation within a metallic cage to protect them from herbivory of green iguanas. Plants were in the acclimation process for 2 weeks, and they were watered twice a week. In the nursery, air temperature was measured from $29-37^{\circ} \mathrm{C}$ and relative humidity from $46-60 \%$ using a hygrometer. Soil temperature was measured from $27-32^{\circ} \mathrm{C}$ with a soil thermometer.

After acclimation, plants were transplanted into the wild populations areas to perform species reintroductions as reinforcement. Two reintroductions were made for Population 1 and one for Population 2 for a total of three. The first transplant was made near Plot 1 in an area without vegetation inside 2 quadrants that measured $1 \mathrm{~m} \times 1 \mathrm{~m}$. Each plant was placed in the corners of the quadrants, except one that was placed in the middle. Both quadrants contained 5 plants for a total of 10 plants planted. The second transplant near Plot 1 was made inside a plot that measured $12 \mathrm{~m}$ long x $2 \mathrm{~m}$ wide. The area was weeded first and then marked with flags. A total of 16 plants were planted. The third transplant was made in an open area without vegetation in a plot that measured $3 \mathrm{~m}$ long x $2 \mathrm{~m}$ wide near Plot 2. This plot was marked with flags in the corners, and 3 plants were planted. Overall, 29 plants were reintroduced to the natural habitat. All individuals were identified with a metallic tag and a number, and plant survival was recorded monthly. Finally, the second transplant near Plot 1 was observed to examine the reproduction of reintroduced plants $(n=16)$. Buds, flowers, and fruits were identified by plant weekly to determine the proportion of plants reproducing out of all plants alive. 


\section{Data analysis}

The statistical analysis of data was made in RStudio and XLSTAT using hypothesis tests and linear models. The two independent samples T test was used to compare means of soil nutrients and $\mathrm{pH}$, plant abundance, and plant height between Population 1 and Population 2. The Mann Whitney U test was done to compare the distribution of soil nutrients and $\mathrm{pH}$, seed germination, seed weight, and plant reproduction between Population 1 and Population 2. Finally, we tested linear regressions between seed weight and plant height and soil $\mathrm{pH}$ and seed germination percent.

\section{Results}

\section{Soil chemistry}

Soil nitrate and nitrite, nitrogen, phosphorus, and organic matter content between plots were found to be equal in means $(P>0.05 ; t=-0.49$ to $1.14 ; d f=16)$. Copper and zinc concentrations among plots were found to be equal in distribution $\left(P>0.05 ; U_{\mathrm{cu}}=28 ; U_{\mathrm{zn}}=32\right)$. We found statistically significant differences in the means of iron, manganese, nickel, and soil pH between plots $\left(P<0.05 ; t_{\mathrm{fe}}=2.86 ; t_{\mathrm{mn}}=5.78 ; t_{\mathrm{ni}}=-2.89 ; t_{\mathrm{pH}}=3.37 ; d f=16\right)$. Iron and manganese average concentrations were higher in Plot 1 (Fig. 2). Nickel average concentration was higher in Plot 2 (Fig. 2). Average soil pH was higher in Plot 1 and lower in Plot 2 (Table 1).

\section{Plant abundance, reproduction, and seed weight}

There was no significant difference in the means of plant abundance between populations in the field $(P>0.05 ; t=0.4 ; d f=3)$. We found 33 seedlings, 59 juveniles, and 207 adults in Plot 1 for a total of 299 plants. In Plot 2, we found 20 juveniles and 116 adults for 136 plants in total. There was no significant difference in the distribution of the number of seeds per fruit between populations in the field $(P>0.05 ; U=6041)$. In our sample, Population 1 produced 393 seeds and Population 2 produced 365 seeds. There was no significant difference in the distribution of seed weight between populations $(P>0.05 ; U=2513)$. Average seed weight was $0.0035 \mathrm{~g}$ in Population 
1 and $0.0034 \mathrm{~g}$ in Population 2. We found a significant positive linear relationship between seed weight and average plant height $(P<0.05 ; P=0.021 ; F=5.64 ; t=2.4 ; \operatorname{Pr}>t=0.021 ; m=1353$; $R^{2}=0.067 ; d f=64$; Fig. 3 ). As a result, plant height increased with seed weight.

\section{Seed germination}

Seed germination was achieved by the extension of the radicle and followed by the emergence of cotyledons and the decay of the seed coat (Fig. 1c). Seeds germinated in the seed starting systems (Fig. 1b). Laboratory conditions used for seed germination and plant growth were found to be effective. Air temperature was registered at a minimum of $28^{\circ} \mathrm{C}$ and a maximum of $31^{\circ} \mathrm{C}$. Relative humidity was registered at a minimum of $49 \%$ and a maximum of $52 \%$. Soil temperature ranged between $31^{\circ} \mathrm{C}$ and $34^{\circ} \mathrm{C}$. Finally, the water $\mathrm{pH}$ was measured at 7.63 .

Heavy seeds germinated and lightweight seeds did not. Seeds that germinated weighted between $0.0021-0.0051 \mathrm{~g}$, and seeds that did not germinated weighted between $0.0004-0.0020 \mathrm{~g}$. There was no significant difference in the distribution of germinated seeds by days among populations in the laboratory $(P>0.05 ; U=1497)$. Seed germination began in day 2 , and the highest germination was achieved in the first 8 days (Fig. 5). In general, most seeds germinated in the first 3 weeks. The seed germination percent was different between populations (Table 1). Population 2 with 44\% had a higher germination capacity.

The seed germination percent in different soils was variable. Seeds germinated in potting soil, pellets, and potting mix and sand, but did not germinated in garden soil (Table 1). Field germination percent near Plot 1 at November resulted in $0 \%$ and near Plot 2 and in the new area in March resulted in 0\% (Table 1). After 5 months, no seed germinated in the field. Instead, other species germinated and grew in the plots. We found a significant negative linear relationship between average soil $\mathrm{pH}$ and seed germination percent $(P<0.1 ; P=0.055 ; F=17 ; t=-4.1$; $\operatorname{Pr}>t=0.055 ; m=-17 ; R^{2}=0.84 ; d f=2$; Fig. 6 ). The seed germination percent increased when average soil $\mathrm{pH}$ decreased.

\section{Plant growth}

Plants grew in the seed starting systems (Fig. 1b). There was a significant difference in the means of plant height between the experimental and control groups in the laboratory 
$(P<0.05 ; t=2.74, d f=190)$. Plant height increased with time in average and was higher in Population 1, the experimental group (Fig. 7). In general, plants doubled the average height of half time in week 8 .

\section{Acclimation and reintroductions}

Plants acclimated to the semi-natural conditions in the nursery environment. We observed plant mortality in the laboratory before acclimation and in the nursery during acclimation. Field transplantation was possible from plants grown in the laboratory and nursery. Plants reintroduced in populations for reinforcement had variation in survival rate. The survival percent of reintroduced plants in Population 1 started high in the first months, but survival decreased to $0 \%$ in the last 2 months. In contrast, reintroduced plant survival (33\%; 1 plant) was constant in Population 2 during the 5 months. Reintroduced plants acclimated to the natural conditions and achieved reproductive maturity through time. The percent of plants reproducing in the first two weeks reached $80 \%$ and then decreased. Finally, the percent of plants producing buds, flowers, and fruits increased to $80 \%$ at week 10 and remained constant until week 12 .

\section{Discussion}

\section{Soil chemistry}

The fire caused a significant increase in soil $\mathrm{pH}$, iron, and manganese and a decrease in nickel after 2 years of the fire. Our hypothesis was supported by the increase in soil $\mathrm{pH}$, iron, and manganese in Plot 1. The other nutrients remained similar between plots suggesting leaching in Plot 1. Nutrients like nitrogen and phosphorus can be leached by rainfall and lost from the burned ecosystem decreasing to pre-fire levels (Kutiel and Naveh 1987). Fires have been found to significantly increase soil pH (Kutiel and Naveh 1987, Norouzi and Ramezanpour 2013, Amoako and Gambiza 2019), specifically, high intensity fires significantly increase soil pH (Bridges et al. 2019).

Higher concentrations of iron and manganese and a lower level of nickel in the burned environment could be due to the increased soil $\mathrm{pH}$ value. Changes in soil micronutrients can be caused by high intensity fires and can be related to soil pH (Norouzi and Ramezanpour 2013). In agreement, reducing soil pH increases nickel accumulation (Nkrumah et al. 2019). Results have 
further suggested that burning enhances the availability of some soil nutrients on topsoil for a short period being an unsustainable way of increasing soil productivity (Amoako and Gambiza 2019). Besides fire, agricultural lime can be used to increase soil $\mathrm{pH}$ and soil nutrient availability (Ritchey et al. 2016).

\section{Plant reproduction and seed weight}

Results showed no effect of fire in reproduction, seed weight, seed germination, and plant abundance. Contrary to our results, seeds number and seed weight of a wheat species were higher in the recently burned soil (Kutiel and Naveh 1987). For only some species, fruit set was significantly greater in the burned environment (Paritsis et al. 2006). Moreover, fire intensity was found to increase the fruit production of Chamaecrista keyensis at short term (Liu et al. 2005). The no effect of fire in the study species is understandable because legumes have shown to be resistant to fire (Fidelis et al. 2016). These show that fire effects on plants, especially reproduction, can be variable depending on the species, fire intensity and frequency, nutrient availability, and aboveground competition (Liu et al. 2005).

\section{Seed germination}

Germination and propagation from seeds were possible in laboratory conditions. Chamaecrista glandulosa var. mirabilis may require temperatures around $31-34{ }^{\circ} \mathrm{C}$ and high soil moisture for seed germination. The germination percent in the field was $0 \%$ in November and March. This suggests that natural conditions were not adequate for germination during these months and germination possibly occurs in the field close to August or September where conditions are favorable. Distinct effects of heat on germination rates have been found in Fabaceae species (Silveira and Overbeck 2013). Environmental factors related to the breaking of

dormancy (e.g., temperature fluctuations, soil moisture) might play a more important role in seed germination than the insufficient direct effect of fire-related high temperatures exposure (Fidelis et al. 2016).

Seed germination was related to soil $\mathrm{pH}$ in the species, as we previously hypothesized. Soil $\mathrm{pH}$ explained $84 \%$ of the variance of seed germination percent. This result indicates that seed germination is highly predicted by soil $\mathrm{pH}$, suggesting that $C$. glandulosa var. mirabilis is adapted to acid silica sand soils. Germination responds with a high percent at the acid low $\mathrm{pH}$ of 
silica sand soil and germination does not occur at the neutral $\mathrm{pH}$ of garden soil. This finding is consistent with previous results where grass species seeds showed better germination towards the acidic range (Singh et al. 1975). This may be because the acidic medium favors the synthesis, action (Singh et al. 1975), and/or function of enzymes (Gafar et al. 2018) necessary for germination. Although there was no significant difference in the seed germination rate, our results of seed germination predictions by soil $\mathrm{pH}$ and a higher germination capacity at $4.8 \mathrm{pH}$ suggest that large increases towards neutral $\mathrm{pH}$ caused by fires could reduce or inhibit seed germination in the species.

\section{Plant growth and size}

Results showed an effect of post-fire soil nutrients on the species, partially supporting our hypothesis. Greater plant height through time in the experimental group, Population 1, could have resulted because of higher iron and manganese and lower nickel concentrations in the soil. Iron deficiency can affect plants (Norouzi and Ramezanpour 2013), so iron and manganese sufficiency can positively affect plant growth. Also, reducing soil $\mathrm{pH}$ increases nickel in plants and decreases shoot biomass and growth (Nkrumah et al. 2019). Studies have reported that natural charcoal and a short-term flush of mineral elements in the soil caused by fire is followed by a positive effect on the growth of herbaceous plants (Kutiel and Naveh 1987, Gundale and DeLuca 2006). Our results confirm that fires significantly increase soil $\mathrm{pH}$ and cause changes in soil micronutrients that can significantly increase plant growth.

Plant height was found to be positively related to seed weight, consistent with our hypothesis. This result is in line with previous studies that have found a positive correlation between seed weight and plant size (Hendrix 1984) and a positive correlation between seed mass and shoot length (Mukherjee et al. 2019). Heavy seeds having big embryos and endosperms can produce higher plants. Large seeds may have larger embryos resulting in bigger seedlings (Xu et al. 2016). As a management strategy, heavy seeds can be used for propagation having a higher germination percent (Anjusha et al. 2015, Xu et al. 2016) and producing bigger plants that can have high survival (Schreeg et al. 2005, Dollard 2018) and reproduction (Rojas-Sandoval and Meléndez-Ackerman 2011).

\section{Reintroductions}


Species reintroductions could be done in both populations. Reintroduced plants were able to survive and reproduce through time in the natural habitat. Their survival decreased to $0 \%$ in Population 1 due to natural disturbances. Mortality in the first reintroduction in Population 1 was caused by Hurricane María in September 2017. Deaths were due to an uprooted large canopy tree that crushed and bended the plants, as happened for another shrub species in response to a hurricane (Pascarella 1998). Mortality in the second reintroduction in Population 1 was caused by a horse grazing and trampling in the area. This same threat was detected in other study along sheep, cattle, and pig grazing (Fenu et al. 2011).

\section{Future research and management}

Future research could consider experimental species reintroductions. Conservation genetics can be incorporated to develop strategies for the preservation of genetic diversity and ultimately the conservation of biodiversity (Pertoldi et al. 2007). Studies could be designed to test different temperature, humidity, and $\mathrm{pH}$ treatments for optimal seed germination and plant growth in the laboratory and field. The development of fire control lines and horse exclusion fences in the natural reserve, landscape maintenance, invasive species prevention, control and eradication, and monitoring are management strategies recommended. Finally, controlled fires can be utilized in vegetated areas for species reintroductions to achieve the preservation of the species.

\section{Conclusions}

In conclusion, large size plants are produced from high weight seeds. Ex situ propagation from seeds was an efficient method for the ex situ conservation of C. glandulosa var. mirabilis. Augmentation of populations was a viable technique following ex situ conservation. Ex situ conservation and species reintroduction were feasible conservation strategies for the species that should be integrated with in situ conservation. Species recovery actions, ecological restoration (Heywood 2017), threats control, and landscape conservation are in situ conservation strategies that can be implemented to protect and preserve the species and its ecosystem.

\section{Acknowledgements}


We thank Ana G. Méndez University for its laboratory and materials. Specially, we are grateful with Julita Rivera, Dawin Santiago, and Armando Canchani for their support in the laboratory. Also, we are grateful with Christian Velez, MSEM and José J. Fumero, Ph.D. for the manuscript revision. Finally, we acknowledge the Department of Natural and Environmental Resources of Puerto Rico for access to RNLT and the species (permit number: 2014-EPE-031).

\section{Authors Contribution}

Conceptualization, F.J.V.T. and J.A.L.C.; Methodology, F.J.V.T. and J.A.L.C.; Investigation, F.J.V.T. and J.A.L.C.; Data Curation, F.J.V.T.; Software, F.J.V.T.; Validation, F.J.V.T.; Formal Analysis, F.J.V.T.; Visualization, F.J.V.T.; Writing - Original Draft, F.J.V.T.; Writing - Review \& Editing, F.J.V.T. and J.A.L.C.; Resources, J.A.L.C.; Supervision, J.A.L.C.; Project Administration, J.A.L.C.

\section{Literature Cited}

Adeney, J.M., N.L. Christensen, A. Vicentini, and M. Cohn-Haft. 2016. White-sand Ecosystems in Amazonia. Biotropica 48:7-23.

Amoako, E.E., and J. Gambiza. 2019. Effects of anthropogenic fires on some soil properties and the implications of fire frequency for the Guinea savanna ecological zone, Ghana. Scientific African 6.

Anjusha, J.R., K. Vidyasagaran, V. Kumar, and R. Ajeesh. 2015. Effect of Seed Weight on Germination and Seedling Characters of Anacardium Occidentale L.: An Important Plantation Crop of India. Plant Archives 15:595-601.

Bewley, J.D. 1997. Seed Germinationand Dormancy. The Plant Cell 9:1055-1066.

Billings, W.D. 1952. The Environmental Complex in Relation to Plant Growth and Distribution. The Quarterly Review of Biology 27:251-265.

Bridges, J.M., G.P. Petropoulos, and N. Clerici. 2019. Immediate Changes in Organic Matter and Plant Available Nutrients of Haplic Luvisol Soils Following Different Experimental Burning Intensities in Damak Forest, Hungary. Forests 10:453.

Cerabolini, B., R.D. Andreis, R.M. Ceriani, S. Pierce, and B. Raimondi. 2004. Seed germination and conservation of endangered species from the Italian Alps: Physoplexis comosa and Primula glaucescens. Biological Conservation 117:351-356. 
Dollard, J.J. 2018. Experimental reintroduction of state-endangered beach pea (Lathyrus japonicus) to Indiana Dunes National Lakeshore. Park Science 34:47-53.

Fenu, G., E. Mattana, and G. Bacchetta. 2011. Distribution, status and conservation of a Critically Endangered, extremely narrow endemic: Lamyropsis microcephala (Asteraceae) in Sardinia. Oryx 45:180-186.

Fidelis, A., L.F. Daibes, and A.R. Martins. 2016. To resist or to germinate? The effect of fire on legume seeds in Brazilian subtropical grasslands. Acta Botanica Brasilica 30:147-151.

Gafar, N.Y., M.M. Hassan, A.M.E. Rugheim, A.G. Osman, M.E. Abdelgani, and A.G.T. Babiker. 2018. Influence of acetic acid, $\mathrm{pH}$ and buffers on Striga hermonthica seeds germination. Journal of Agriculture and Veterinary Science 11:74-78.

Godefroid, S., C. Piazza, G. Rossi, S. Buord, A.D. Stevens, R. Aguraiuja, C. Cowell, C.W. Weekley, G. Vogg, J.M. Iriondo, I. Johnson, B. Dixon, D. Gordon, S. Magnanon, B. Valentin, K. Bjureke, R. Koopman, M. Vicens, M. Virevaire, and T. Vanderborght. 2011. How successful are plant species reintroductions? Biological Conservation 144:672-682.

Gómez-Gómez, F., J. Rodríguez-Martínez, and M. Santiago. 2014. Hydrogeology of Puerto Rico and the outlying islands of Vieques, Culebra, and Mona. Scientific Investigations Map 3296, USGS.

Guerrant Jr, E.O., and T.N. Kaye. 2007. Reintroduction of rare and endangered plants: common factors, questions and approaches. Australian Journal of Botany 55:362.

Gundale, M.J., and T.H. DeLuca. 2006. Charcoal effects on soil solution chemistry and growth of Koeleria macrantha in the ponderosa pine/Douglas-fir ecosystem. Biology and Fertility of Soils 43:303-311.

Hendrix, S.D. 1984. Variation in Seed Weight and its Effects on Germination in Pastinaca Sativa L. (Umbelliferae). American Journal of Botany 71:795-802.

Heywood, V.H. 2017. The future of plant conservation and the role of botanic gardens. Plant Diversity 39:309-313.

Hunt, R. 2003. Growth Analysis, Individual Plants. Elsevier.

Knelman, J., E. Graham, S. Ferrenberg, A. Lecoeuvre, A. Labrado, J. Darcy, D. Nemergut, and S. Schmidt. 2017. Rapid Shifts in Soil Nutrients and Decomposition Enzyme Activity in Early Succession Following Forest Fire. Forests 8:347. 
Kutiel, P., and Z. Naveh. 1987. The effect of fire on nutrients in a pine forest soil. Plant and Soil 104:269-274.

Liogier, H.A. 1988. Descriptive Flora of Puerto Rico and Adjacent Islands: Leguminosae to Anacardiaceae. Editorial de la Universidad de Puerto Rico, San Juan, Puerto Rico.

Liu, H., E.S. Menges, J.R. Snyder, S. Koptur, and M.S. Ross. 2005. Effects of Fire Intensity on Vital Rates of an Endemic Herb of the Florida Keys, USA. Natural Areas Journal 25:7176.

McIntosh, M.E. 2002. Plant size, breeding system, and limits to reproductive success in two sister species of Ferocactus (Cactaceae). Plant Ecology 162:273-288.

Miller, G.L., and A.E. Lugo. 2009. Guide to the Ecological Systems of Puerto Rico. Gen. Tech. Rep. IITF-GTR-35. USDA, Forest Service, IITF. 437.

Mukherjee, J.R., T.A. Jones, T.A. Monaco, and P.B. Adler. 2019. Relationship Between Seed Mass and Young-Seedling Growth and Morphology Among Nine Bluebunch Wheatgrass Populations. Rangeland Ecology \& Management 72:283-291.

Nkrumah, P.N., G. Echevarria, P.D. Erskine, R.L. Chaney, S. Sumail, and A. van der Ent. 2019. Effect of nickel concentration and soil $\mathrm{pH}$ on metal accumulation and growth in tropical agromining 'metal crops.' Plant and Soil 443:27-39.

Norouzi, M., and H. Ramezanpour. 2013. Effect of Fire on Chemical Forms of Iron and Manganese in Forest Soils of Iran. Environmental Forensics 14:169-177.

Paritsis, J., E. Raffaele, and T.T. Veblen. 2006. Vegetation disturbance by fire affects plant reproductive phenology in a shrubland community in northwestern Patagonia, Argentina. New Zealand Journal of Ecology 30:387-395.

Pascarella, J.B. 1998. Resiliency and Response to Hurricane Disturbance in a Tropical Shrub, Ardisia Escallonioides (Myrsinaceae, in South Florida. American Journal of Botany 85:1207-1215.

Pellegrini, A.F.A., A. Ahlström, S.E. Hobbie, P.B. Reich, L.P. Nieradzik, A.C. Staver, B.C. Scharenbroch, A. Jumpponen, W.R.L. Anderegg, J.T. Randerson, and R.B. Jackson. 2018. Fire frequency drives decadal changes in soil carbon and nitrogen and ecosystem productivity. Nature 553:194-198. 
Pertoldi, C., R. Bijlsma, and V. Loeschcke. 2007. Conservation genetics in a globally changing environment: present problems, paradoxes and future challenges. Biodiversity and Conservation 16:4147-4163.

Ren, H., S. Jian, H. Liu, Q. Zhang, and H. Lu. 2014. Advances in the reintroduction of rare and endangered wild plant species. Science China Life Sciences 57:603-609.

Ritchey, E.L., L.W. Murdock, D. Ditsch, J.M. McGrath, and F.J. Sikora. 2016. Agricultural Lime Recommendations Based on Lime Quality. Cooperative Extension Service, University of Kentucky.

Rodríguez-Robles, J.A., E.J. Meléndez, and J.D. Ackerman. 1992. Effects of display size, flowering phenology, and nectar availability on effective visitation frequency in Comparettia falcata (Orchidaceae). American Journal of Botany 79:1009-1017.

Rojas-Sandoval, J., and E. Meléndez-Ackerman. 2011. Reproductive phenology of the Caribbean cactus Harrisia portoricensis : rainfall and temperature associations. Botany 89:861-871.

Schreeg, L.A., R.K. Kobe, and M.B. Walters. 2005. Tree seedling growth, survival, and morphology in response to landscape-level variation in soil resource availability in northern Michigan. Can. J. For. Res. 35:263-273.

Shen, S.K., F.Q. Wu, G.S. Yang, Y.H. Wang, and W.B. Sun. 2015. Seed germination and seedling emergence in the extremely endangered species Rhododendron protistum var. giganteum - the world's largest Rhododendron. Flora - Morphology, Distribution, Functional Ecology of Plants 216:65-70.

Silveira, F.S., and G.E. Overbeck. 2013. Effect of high temperature on germination of four legumes from a forest-grassland mosaic in Southern Brazil. Biota Neotrop. 13.

Singh, V.P., S.L. Mall, and S.K. Billore. 1975. Effect of $\mathrm{pH}$ on Germination of Four Common Grass Species of Ujjain (India). Journal of Range Management 28:497-498.

Soulé, M.E. 1985. What is Conservation Biology? BioScience 35.

USFWS. 1994. Chamaecrista glandulosa var. mirabilis Recovery Plan. Page 18. USFWS, Atlanta, Georgia.

USFWS. 2015. Chamaecrista glandulosa var. mirabilis 5-Year Review: Summary and Evaluation. Page 14. USFWS, Boquerón, Puerto Rico. 
bioRxiv preprint doi: https://doi.org/10.1101/2022.03.04.483036; this version posted March 5, 2022. The copyright holder for this preprint (which was not certified by peer review) is the author/funder. All rights reserved. No reuse allowed without permission.

Xu, Y., N. Cai, B. He, R. Zhang, W. Zhao, J. Mao, A. Duan, Y. Li, and K. Woeste. 2016. Germination and early seedling growth of Pinus densata Mast. provenances. Journal of Forestry Research 27:283-294.

\section{Appendix}

Table 1. Seed germination percent on different soils and in the field. The total number of seeds sowed, average organic matter, and average soil $\mathrm{pH}$ are shown for each case. Dashes were placed when data was not acquired.

\begin{tabular}{ccccc}
\hline Soil/Field & Seed germination \% & Sown seeds & $\begin{array}{c}\text { Organic matter } \\
\text { (\%) }\end{array}$ & $\begin{array}{c}\text { Average pH } \\
\text { (S.U.) }\end{array}$ \\
\hline Population 1 (sand) & & & 2.1 & 5.5 \\
Population 2 (sand) & 18 & 324 & 1.5 & 4.8 \\
Potting & 44 & 74 & - & 6.3 \\
Garden & 11 & 108 & - & - \\
Pellets & 0 & 22 & - & - \\
Potting and sand & 27 & 22 & - & - \\
Reinforcement Pop. 1 & 9 & 48 & - & - \\
Reinforcement Pop. 2 & 0 & 48 & - & - \\
New population & 0 & 220 & - & - \\
\hline
\end{tabular}

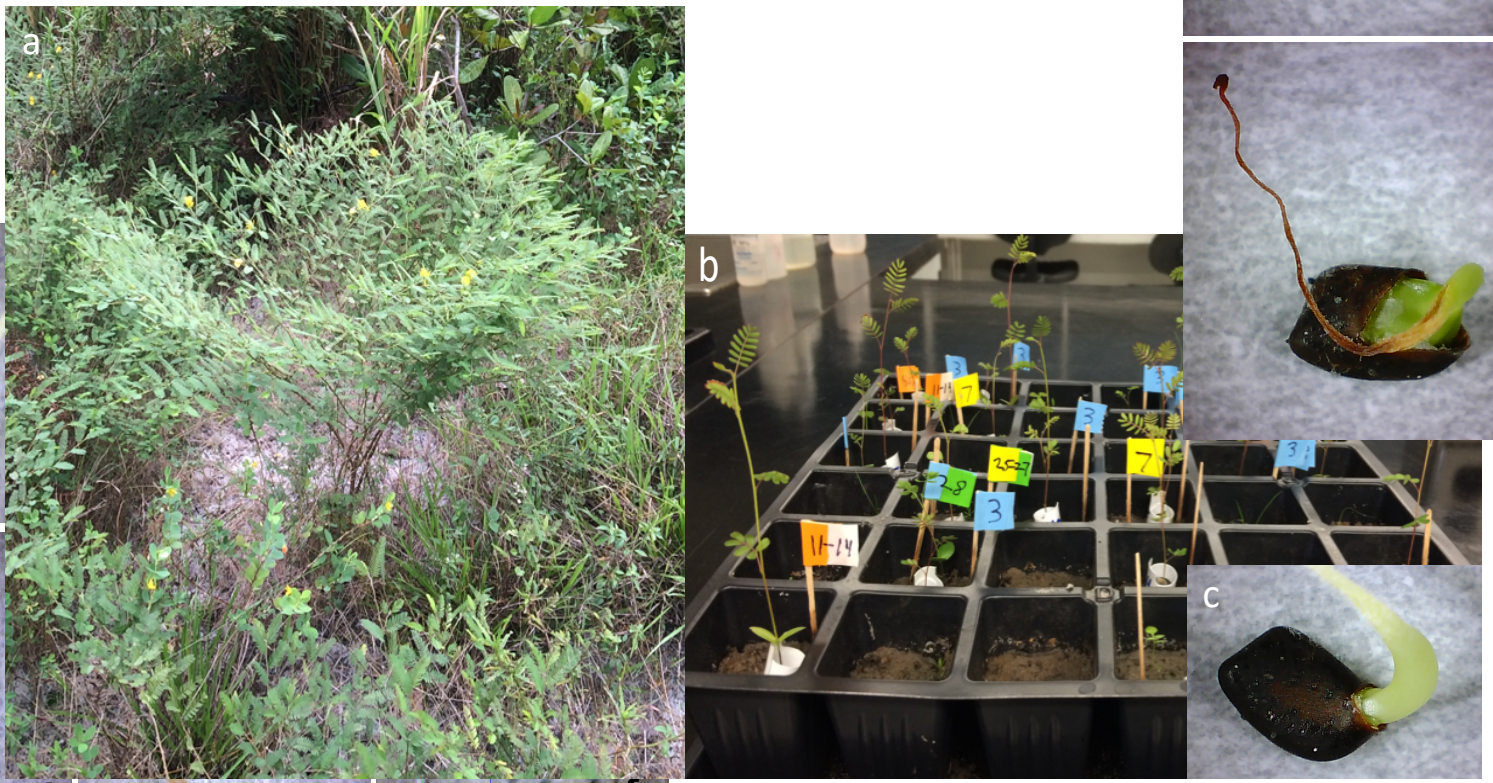

Figure 1. Chamaecrista glandulosa var. mirabilis (a). Plant growth in the systems (b). Seed germination in the laboratory (c). 


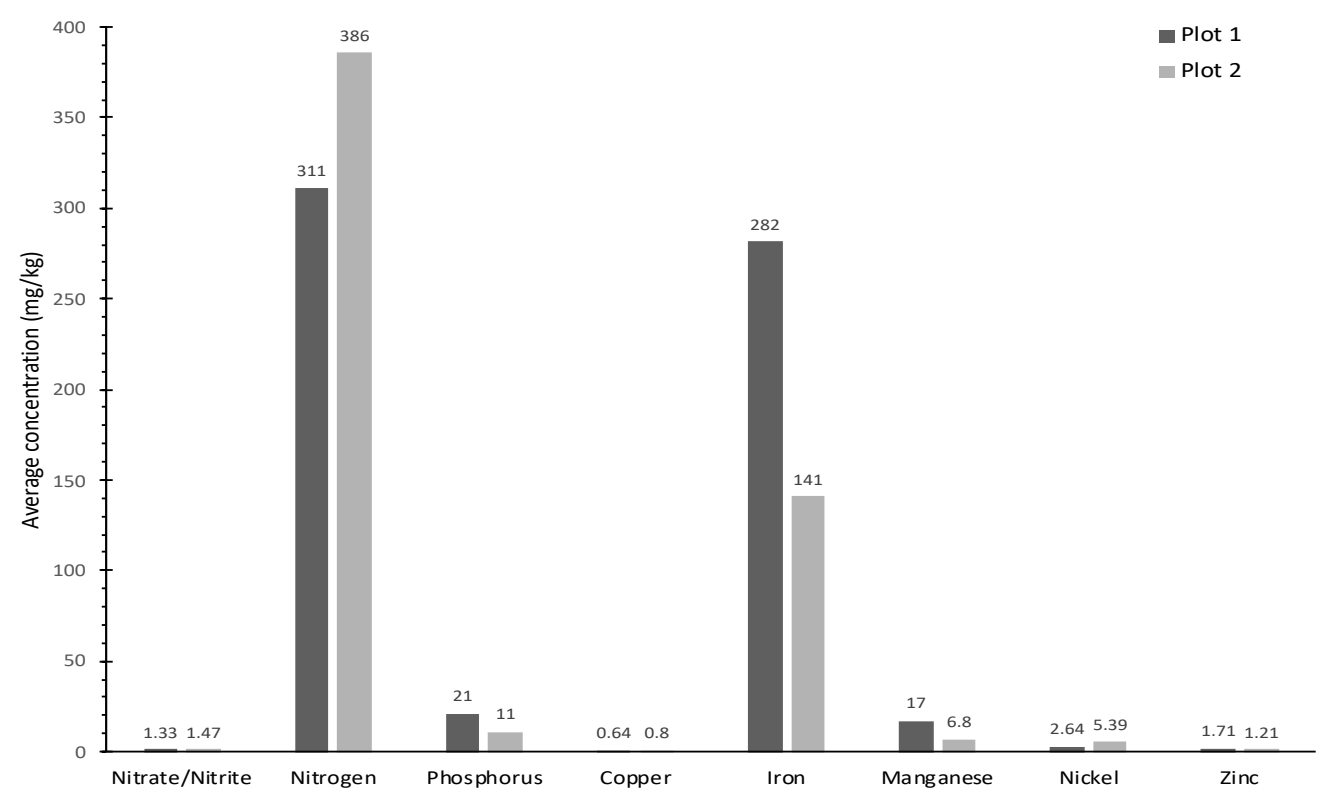

Figure 2 . Soil nutrients by plot. Plot 1 was affected by fire. Plot 2 was not affected by fire.

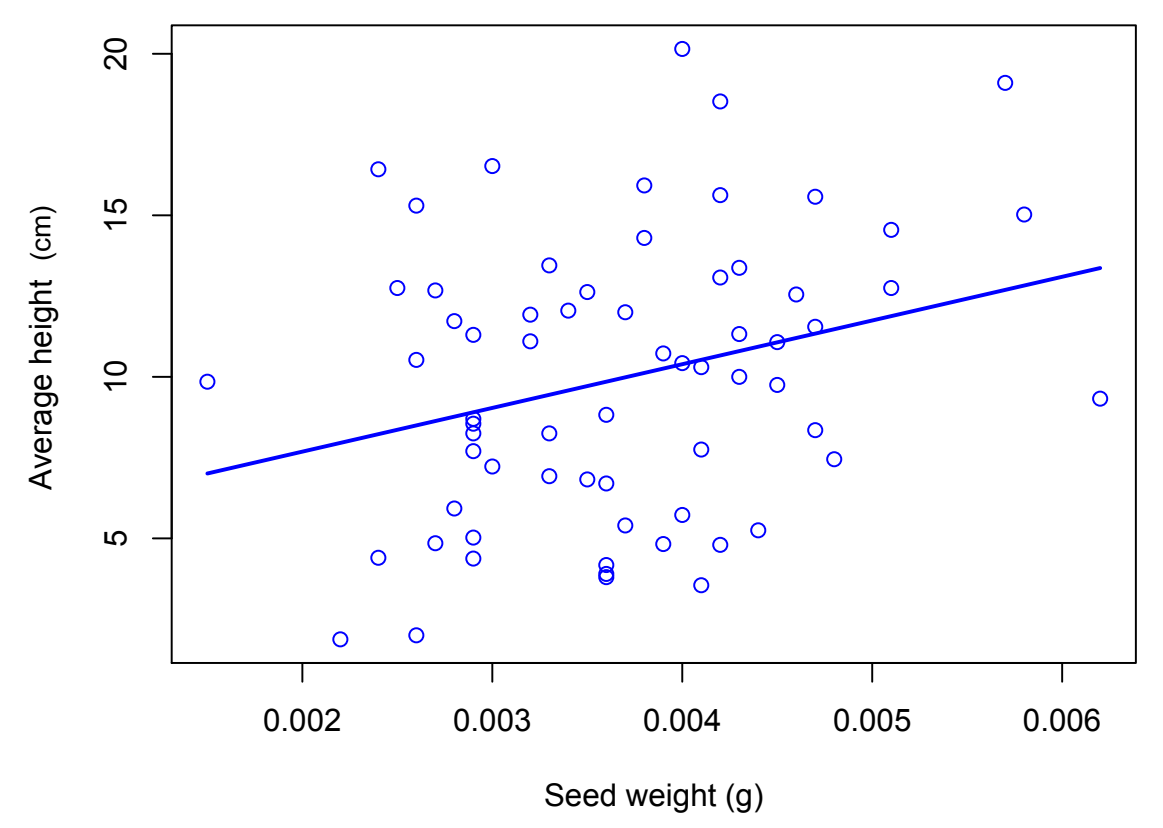

Figure 3. Positive linear relationship between seed weight and plant height. 


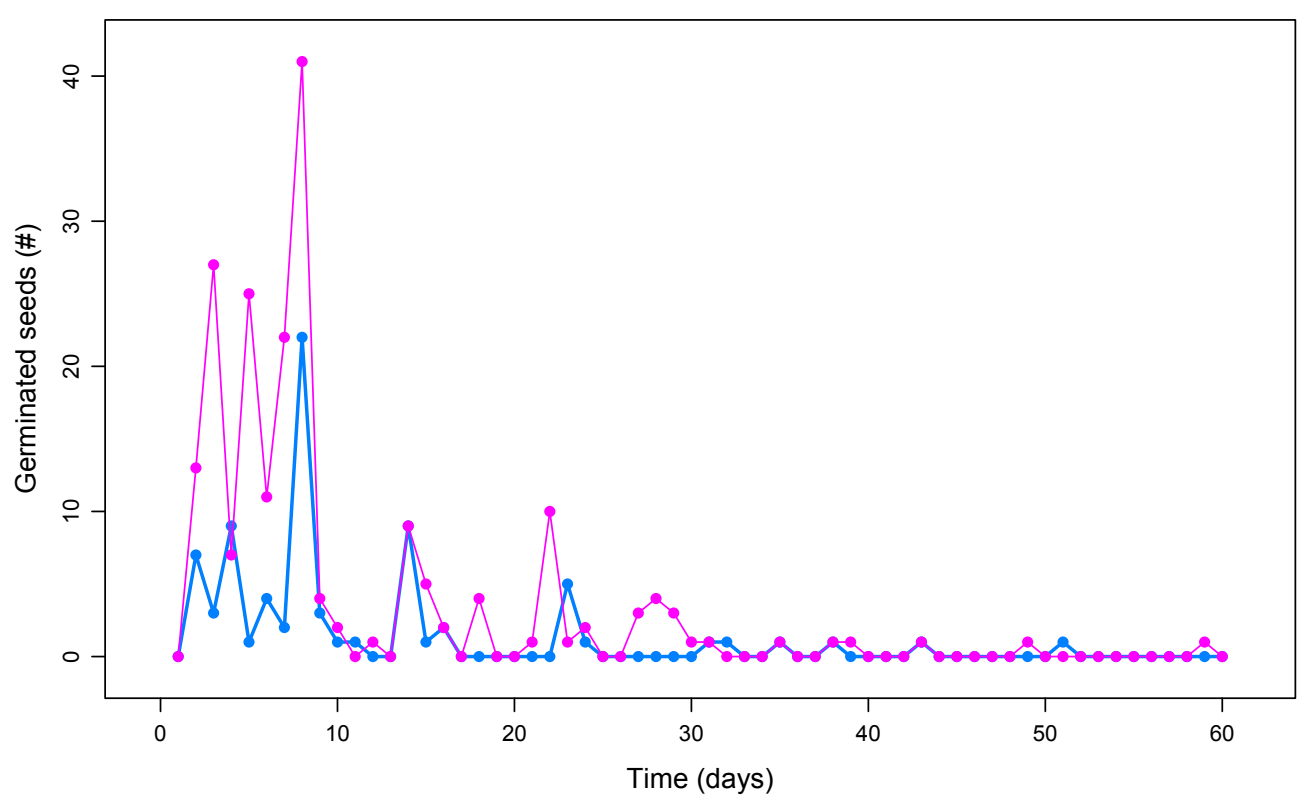

Figure 5 . Seed germination rate by population. Population 1 , the experimental group, is shown in blue. Population 2, the control group, is shown in pink. 
bioRxiv preprint doi: https://doi.org/10.1101/2022.03.04.483036; this version posted March 5, 2022. The copyright holder for this preprint (which was not certified by peer review) is the author/funder. All rights reserved. No reuse allowed without permission.

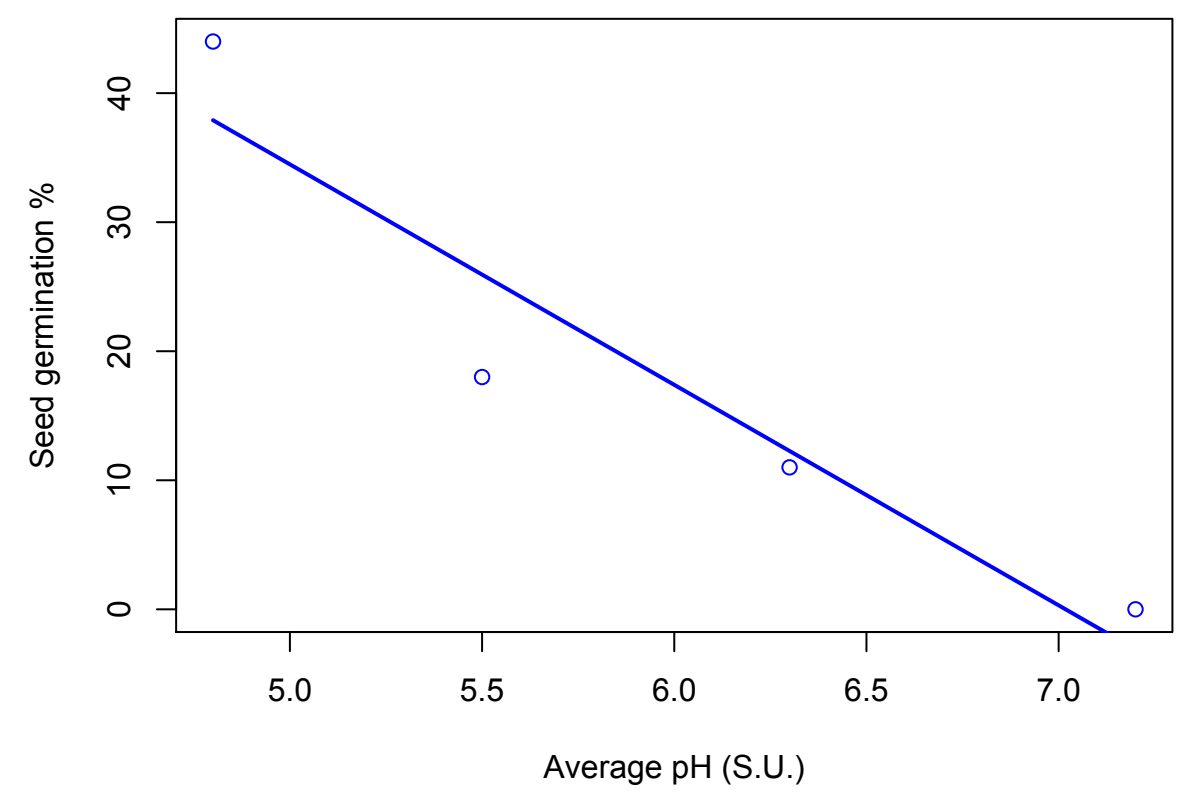

Figure 6. Negative linear relationship between soil pH and seed germination percent. 
bioRxiv preprint doi: https://doi.org/10.1101/2022.03.04.483036; this version posted March 5, 2022. The copyright holder for this preprint (which was not certified by peer review) is the author/funder. All rights reserved. No reuse allowed without permission.

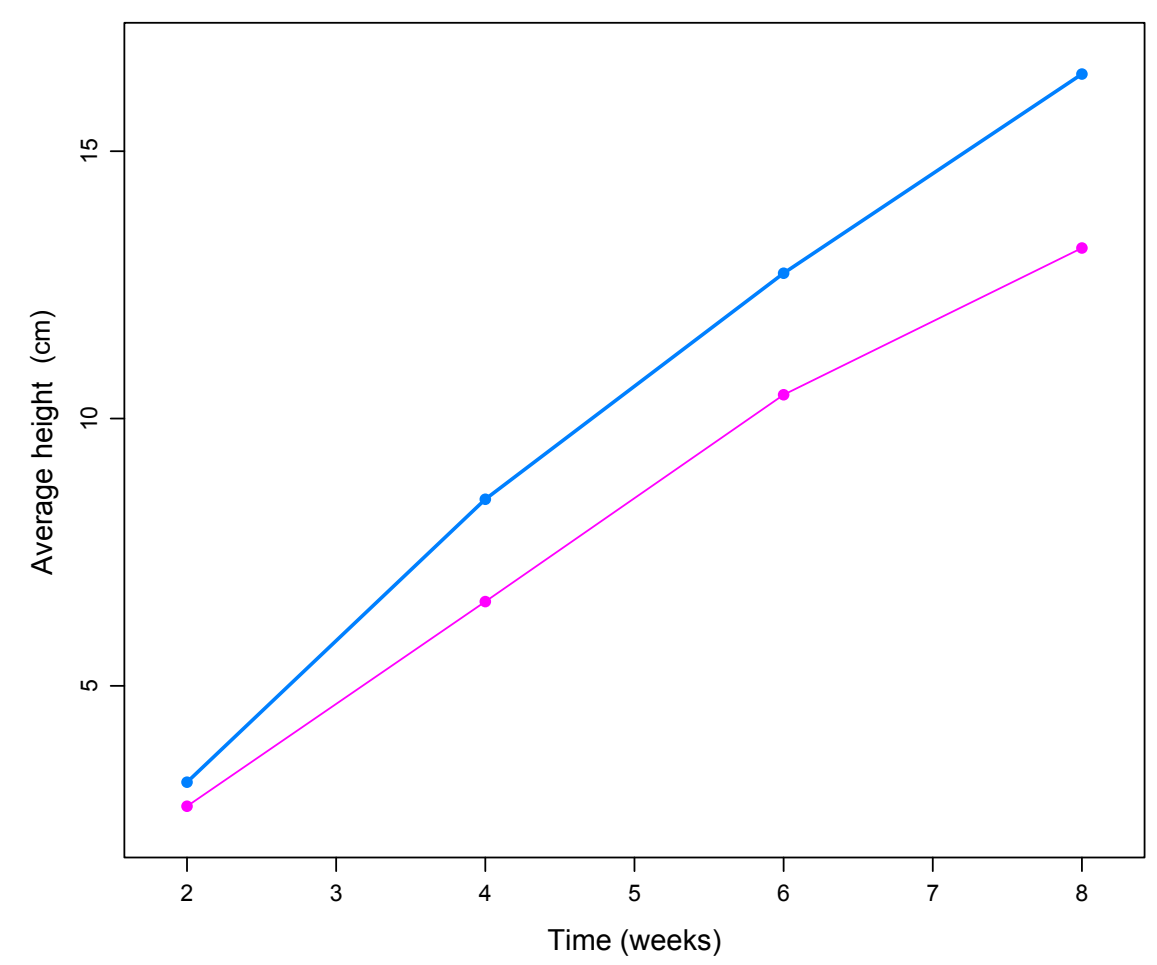

Figure 7. Plant growth by population. Population 1, the experimental group, is shown in blue. Population 2, the control group, is shown in pink. 